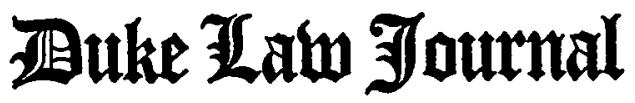

\section{RECENT TRENDS IN ANTTTRUST CIVIL ACTION DAMAGE DETERMINATIONS $\dagger^{\dagger}$}

\author{
DAVid B. WeINBERG*
}

INTRODUCTION

I. Proof of Legal InJURY and the Amount of Damages
A. The Supreme Court Precedent
B. Burden of Proof Distinctions in the Lower Courts

II. "Pass-ON" and Damages
A. The Hanover Shoe Standard
B. Lower Court Pass-On Cases

III. Measures of Damage Amounts
A. Methods of Proof: Theory
B. Methods of Proof: Application
C. Good Will or Fair Market Value as Duplicative of Future Profits
D. Offsets and Mitigation
E. Jury Knowledge of Trebling

IV. Other Damages Issues
A. The Fruits of Anticompetitive Actions
B. Attorneys' Fees

V. Conclusion

\section{INTRODUCTION}

A plaintiff who seeks to recover under section 4 of the Clayton Act $^{1}$ must show (1) a violation of the antitrust laws, (2) legal injury to

$\dagger$ Copyright (C) 1975 by American Law Institute. All rights reserved. Published with permission.

The original version of this Article was published in a book of study materials prepared for the ALI-ABA Course of Study on the Private Antitrust Action: Standing and Damages, which was held first in June 1975 in Los Angeles and again in November in Washington, D.C.

* Attorney, Wald, Harkrader \& Ross, Washington, D.C. B.A. 1970, Yale University; J.D. 1973, University of Pennsylvania; LL.M. 1974, Georgetown University.

1. 15 U.S.C. $\$ 15$ (1970). 
his business or property-including both the fact of some damage and a causative link between this damage and the defendant's violation - and (3) the amount of damages suffered." "Danages" thus enters into the determination twice: once as an element of legal mjury and once as a showing of amount of loss. This Article will examine these two statutory elements. ${ }^{3}$

The first section of the Article discusses the development of distinctions in the burdens to be met im proving the "fact of injury" and the "amount of damage," and suggests that the Supreme Court has, in its more recent decisions, de-emphasized these distinctions. ${ }^{4}$ The remaming sections address the pass-on issue ${ }^{5}$ and several more concrete judicial

2. Section 4 provides:

Any person who shall be injured in his business or property by reason of anything forbidden in the antitrust laws may sue therefor ... and shall recover threefold the damages by him sustained, and the cost of suit, including a reasonable attorney's fee. Id.

With respect to the elements one must prove in order to recover, see, e.g., Terrell v. Household Goods Carriers' Bureau, 494 F.2d 16, 20 (5th Cir.), petition for cert. dismissed, 419 U.S. 987 (1974), and cases cited therein.

3. The question of the "damages" incurred by a plaintiff (or plaintiffs) in a contemporary civil antitrust case can also arise in two other contexts, at relatively preliminary stages of the proceedings. In a class action, the question may be important in the determination of the commonality of interests of an alleged class. See, e.g., Herrmann v. Atlantic Richfield Co., 65 F.R.D. 585 (W.D. Pa. 1974); Kinzler v. New York Stock Exch., 62 F.R.D. 196 (S.D.N.Y. 1974); Bill Minielli Cement Contracting, Inc. v. Richter Concrete Corp., 62 F.R.D. 381 (S.D. Ohio 1973). The damage question also may arise as part of a challenge to standing. Typically, it is in the context of a pass-on defense. See notes 86-114 infra and accompanying text. This repeated consideration of "damages" makes little analytical sense, but is a result of the pattern of federal litigation -pretrial motions, trial, motions for directed verdict or judgment n.o.v., etc. The damage concepts involved at each stage are actually indistinguishable. Circuit Judge Hays ably described the situation in GAF Corp. v. Circle Floor Co., 463 F.2d 752 (2d Cir. 1972), petition for cert. dismissed, 413 U.S. 901 (1973):

The courts, in interpreting $\$ 4$ of the Clayton Act and its predecessor, have endeavored, although with some inconsistency and conflict, to promote the policy of competition established by the Sherman and Clayton Acts by interpreting $\$ 4$ as allowing treble damages only to those who have suffered some diminution of their ability to compete. Whether viewed in terms of "lack of standing" or the absence of antitrust damages, the courts, in denying recovery to various kinds of plaintiffs, have sought to confine recovery to those who have been injured by restraints on competitive forces in the econoiny. Id. at 757-58.

... [W] thether GAF is viewed as not having "standing to sue" for these alleged violations of the antitrust laws, or, is viewed as not having sustained anticompetitive damages from the particular acts alleged, the result under $\S$

4 is the same.... Id. at 759 .

These contexts are not within the primary concern of this Article; nevertheless, the standing issue receives some unavoidable attention in the discussion of the role of the "pass-on defense" in damage determinations. See text accompanying notes 86-114 infra.

4. Since a significant number of lower courts have failed to adopt this analysis, this section is no doubt the most controversial portion of the Article.

5. The "pass-on" defense is the assertion by an antitrust defendant that the plaintiff 
developments which relate to the proof of specific items of damage. ${ }^{6}$

Recognition that two elements constitute the "legal injury"- -the fact of damage ("shall be injured") 7 and causation ("by reason of anything forbidden") ${ }^{8}$-is vital to an understanding of the cases discussed below. The frailty of the English language often results in confusion, with the words and phrases "injury," "fact of injury," "damages," and "fact of damage" being used synonymously. The involvement of "causation" and "hibility" also frequently muddies the analytical waters. Accurate analysis of the concepts discussed in this Article requires constant sensitivity to the way in which these terms are being used.

A central fact which cannot be avoided by all students of the antitrust laws, be they plaintiffs' attorneys, defense attorneys, or disinterested observers, is the Supreme Court's consistent emphasis on the importance of antitrust policy in our economic system, ${ }^{9}$ and the concomitant recognition of the private civil action as "a vital means for enforcing the antitrust policy of the United States."10 The fundamental policy choice to favor controlled competition over other possible forms of economic organization may or may not be "right" in any philosophical, economic, or political sense. But it is the choice which has guided

has suffered no damages because any higher costs were passéd on to consumers or subsequent purchasers. See notes 86-88 infra and accompanying text.

6. This Article focuses on developments in the area of antitrust civil damages within this decade. Of course, some review of historic precedent is necessary, particularly with respect to the more theoretical analysis. However, there has been no attempt here to write a primer on civil damages, nor to present another discussion of those decisions which have been considered leading cases in the development of damages concepts. The reader interested in a more extensive treatment is referred to the following sources: E. Timberlake, Federal Treble Damage antitrust actions (1965); Clark, The Treble Damage Bonanza: New Doctrines of Damages in Private Antitrust Suits, 52 Mich. L. Rev. 363 (1954); Gibbons, The 'Market Share' Theory of Damages in Private Enforcement Cases, 18 ANTITRusT Bull. 743 (1973); Parker, Measuring Damages in Federal Treble Damage Actions, 17 ANTITRust BulL. 497 (1972); Note, Measuring Damages in Antitrust Cases, 36 AlbanY L. Rev. 773 (1972); Note, Private Treble Damage Antitrust Suits: Measure of Damages for Destruction of All or Part of a Business, 80 HARV. L. REv. 1566 (1967).

7. 15 U.S.C. $\$ 15$ (1970).

8. Id.

9. See, e.g., Hawaii v. Standard Oil Co., 405 U.S. 251, 262 (1972); Northern Pac. Ry. v. United States, 356 U.S. 1, 4 (1958); cf. Gulf States Utility Co. v. FPC, 411 U.S. 747 (1973).

10. Perma Life Mufflers, Inc. v. International Parts Corp., 392 U.S. 134, 136 (1968). See also Hanover Shoe, Inc. v. United Shoe Mach. Corp., 392 U.S. 481, 494 (1968). For a discussion of the Hanover Shoe case, see notes 86-98 infra and accompanying text. 
the law's development, and it provides the thread of consistency which runs through the Supreme Court's decisions.

This policy has produced Supreme Court decisions that give every reasonable advantage to the plaintiff in a private suit. Other legal policies have been given only secondary weight. Thus, the thrust of the Supreme Court's guidance in the civil damages area has been to preserve until the ultimate effort of proof-generally, the trial-all issues which relate to the damages incurred by a plaintiff, and to give plaintiffs all possible benefit of the doubt on these issues. The lower courts, however, have been less sympathetic to plaintiffs, and the Supreme Court's unwillingness to review every case which parties have sought to bring before it has left considerable confusion in several of the areas which this Article will discuss. ${ }^{11}$

\section{i. Proof of Legal InJury and the AMOUNT OF Damages}

\section{A. The Supreme Court Precedent}

Five Supreme Court cases ${ }^{12}$ provide primary gnidance to courts and litigants which face questions of legal injury-including its "fact of damage" and "causation" elements-and the quantum of damage suffered. These cases show that the Supreme Court has moved to a position of permitting plaintiffs in treble damages cases to prevail even if they cannot prove their cause of action under standards applicable in other civil cases.

In Eastman Kodak Co. v. Southern Photo Materials Co., ${ }^{13}$ the first of the Supreme Court's decisions on the burden of proof issue, a photosupply dealer alleged that Kodak had attempted to monopolize the Atlanta photosupply market by refusing to sell the dealer supplies at the normal dealer discounts. The Supreme Court's decision established that some uncertainty was permissible in the "proof" of the anount of

11. This is especially true with respect to the appropriate role of the "pass-on" defense in civil antitrust actions. See notes 86-114 infra and accompanying text.

12. Zenith Radio Corp. v. Hazeltine Research, Inc., 395 U.S. 100 (1969); Continental Ore Co. v. Union Carbide \& Carbon Corp., 370 U.S. 690 (1962); Bigelow v. RKO Radio Pictures, Inc., 327 U.S. 251 (1946); Story Parchment Co. v. Paterson Parchment Paper Co., 282 U.S. 555 (1931); Eastman Kodak Co. v. Southern Photo Materials Co., 273 U.S. 359 (1927).

A sixth Supreme Court case, Hanover Shoe, Inc. v. United Shoe Mach. Corp., 392 U.S. 481 (1968), will be discussed separately later in this Article. See notes 86-98 infra and accompanying text.

13. 273 U.S. 359 (1927). 
damages suffered by an antitrust plaintiff. Quoting the court of appeals decision in the case, the Court held:

"Damages are not rendered uncertain because they cannot be calculated with absolute exactness. It is sufficient if a reasonable basis of computation is afforded, although the result be only approximate ...." Furthermore, a defendant whose wrongful conduct has rendered difficult the ascertainment of the precise damages suffered by the plaintiff, is not entitled to complain that they cannot be measured with the same exactness and precision as would otherwise be possible. ${ }^{14}$

Recognition of this eased burden of proof was accompanied by an emphasis on the proper charge to be given to a civil damages jury. The Court found that the question of the amount of the plaintiff's damage was "properly submitted to the jury" because "[t]he jury was imstructed, in effect, that the amount of the damages could not be determined by mere speculation or guess, but must be based on evidence furnishing data from which the amount of the probable loss could be ascertained as a matter of reasonable inference."15

Thus it was established that proof of the amount of damages suffered could be considerably more speculative than other proofs put before a civil court, a principle that remains viable to this day. ${ }^{16}$ But it should be noted that the above-quoted charge related only to proof of the amount of damages. The question of the fact of damage-an element of legal imjury - was no longer at issue in the case by the time Eastman Kodak reached the Supreme Court. The Court therefore did not comment on the need to prove both the fact and the amount of damages, or on the standard of proof necessary to establish the fact of damage.

A distinction between these proofs was drawn six years later, however, in Story Parchment Co. v. Paterson Parchment Paper Co..$^{17}$ The case had been brought by a parchment manufacturing firm which alleged that the defendant had successfully conspired with two other firms, the only other entrants in the market, to drive the plaintiff out of business. A jury had awarded the plaintiff $\$ 65,000$, subsequently

14. Id. at 379, quoting 295 F. 98, 102 (5th Cir. 1923).

15. 273 U.S. at 379.

16. See, e.g., Zenith Radio Corp. v. Hazeltine Research, Inc., 395 U.S. 100 (1969) (discussed in text accompanying notes 34-38 infra); Terrell v. Household Goods Carriers' Bureau, 494 F.2d 16, 24 (5th Cir.), petition for cert. dismissed, 419 U.S. 987 (1974); Hobart Bros. v. Malcolm T. Gilliland, Inc., 471 F.2d 894, 902 (5th Cir.), cert. denied, 412 U.S. 923 (1973); Farmington Dowel Prod. Co. v. Forster Mfg. Co., 421 F.2d 61, 81 (1st Cir. 1969).

17. 282 U.S. 555 (1931). 
trebled by the district court, but the court of appeals had vacated the judgment. The Supreme Court reinstated it, holding that:

It is true that there was uncertainty as to the extent of the damage, but there was none as to the fact of damage; and there is a clear distinction between the measure of proof necessary to establish the fact that petitioner had sustained some damage and the measure of proof necessary to enable the jury to fix the amount. The rule which precludes the recovery of uncertain damages applies to such as are not the certain result of the wrong, not to those damages which are definitely attributable to the wrong and only uncertain in respect to their amount. ${ }^{18}$

It is important to recognize that the Story Parchment Court was faced with a situation similar to the classic personal injury tort case, in which proof of violation essentially constitutes proof of injury. A plaintiff who shows nothing more than that a defendant's recklessly driven automobile struck him while he was crossing a street has established the fact that he has been imjured. Similarly, the Story Parchment Company alleged that a conspiracy among the established firms in the relevant market had forced it out of business. Any proof of the existence and success of this conspiracy would also plainly be sufficient to show that some injury (fact of damage) had been caused (causation) to the plaintiff. The Story Parchment opinion makes it quite clear that the Court was focusing on this similarity. ${ }^{19}$

But there is no logical reason why this principle should not also be applied to proof of the fact of damage in cases in which even the proof of this fact is made more difficult because of the defendants' actions. The Supreme Court seemed to recognize this in Bigelow v. RKO Radio Pictures, Inc., ${ }^{20}$ in which the Court addressed both the fact-of-damage question and the amount-of-damage question.

The case involved a claim by motion picture theater owners that a conspiracy among film distributors and other theater owners had precluded the plaintiffs from receiving films until long after they had reached their peak of popularity. Chief Justice Stone, writing for the Court, noted that 'it is said, petitioners' evidence does not establish the fact of damage, and that further, the standard of comparison which the evidence sets up is too speculative and uncertain to afford an accurate

18. Id. at 562 (emphasis added).

19. Id. at 563. Justice Sutherland, writing for the Court, explained the holding as follows:

Where the tort itself is of such a nature as to preclude the ascertainment of the amount of damages with certainty, it would be a perversion of fundamental principles of justice to deny all relief to the injured person, and thereby relieve the wrongdoer from making any amend for his acts.

20. 327 U.S. 251 (1946). 
measure of the amount of the damage."21 Noting that the case before it was comparable to Eastman Kodak and Story Parchment, ${ }^{22}$ the Court summarized the holdings of those precedents in language that seemed to extend not only to proof of amount, but to causation and proof of the fact of damage as well:

In each case we held that the evidence sustained verdicts for the plaintiffs, and that in the absence of more precise proof, the jury could conclude as a inatter of just and reasonable inference from the proof of defendants' wrongful acts and their tendency to injure plaintiffs' business, and from the evidence of the decline in prices, profits and values, not shown to be attributable to other causes, that defendants' wrongful acts had caused damage to the plaintiffs. ${ }^{23}$

The evidence here was ample to support $a$ just and reasonable inference that petitioners were damaged by respondents action, whose unlawfulness the jury has found .... The comparison of petitioners' receipts before and after respondents' unlawful action impinged on petitioners' business afforded a sufficient basis for the jury's computation of the damage, where the respondents' wrongful action had prevented petitioners from making any more precise proof of the ainount of the dainage. ${ }^{24}$

The Court appeared to be holding that proof of "wrongful acts," plus proof of the acts' "tendency to injure" plaintiffs, could support "a just and reasonable inference that petitioners were damaged." This language hardly establishes a more stringent burden of proof for the proof of injury-damage plus causation-than for the amount of dainage. At the very least, it suggests that the Story Parchment distinction ${ }^{25}$ between degrees of proof necessary to show the fact of damage and to show the amount of damages had no real substance.

Justice Frankfurter vigorously dissented in Bigelow, precisely because in his view the Court had failed to distinguish sufficiently between proof of the amount of damage and proof of "legal injury." The "real question," he stated, was "whether the respondents" violation of the Sherman Law illegally injured the petitioners." 20 He agreed that Eastman Kodak and Story Parchment were relevant guides for disposition of the case, but did not find "that the decisive distinction made in those cases has been observed in deciding this case." "The distinc-

21. Id. at 263.

22. Id.

23. Id. at 264.

24. Id. at 266 (emphasis added).

25. See 282 U.S. at 562 , discussed in text accompanying notes 17-19 supra.

26. 327 U.S. at 267 (emphasis added).

27. Id. 
tion is between proving that some damages were the certain result of the wrong' and uncertainty as to the dollars and cents value of such injuring wrong." 28 Justice Frankfurter simply was not convinced that "solid proof of the existence of a legal injury" had been adduced. ${ }^{29} \mathrm{He}$ believed it was necessary to do more to show this injury than merely to introduce what Chief Justice Stone had described as evidence of declining "prices, profits and values, not shown to be attributable to other causes. . . ."

Justice Frankfurter correctly characterized the Bigelow majority opinion, but his attempt to maintain the distinctions between proof of legal injury and proof of the amount thereof has proven to have been in vain. In the years since Bigelow, the Supreme Court has twice confirmed that evidence sufficient to support merely an inference of legal injury will support a finding of such injury. One case addressed causation; the other, the fact of damage.

Continental Ore Co. v. Union Carbide \& Carbon Corp..$^{31}$ settled the issue with regard to causation. The case involved alleged monopolization of the vanadiun industry. The sitting Justices-Justice Frankfurter took no part in the consideration of the case-unanimously held ${ }^{32}$ that a plaintiff must be allowed to have his case reach the jury if he has presented "sufficient evidence for a jury to infer the necessary causal connection between respondents' antitrust violations and petitioners' injury."33

Thus, by 1962 the Court had established that proof of both causation and the amount of dainages in antitrust cases could be established inferentially, by evidence that in other cases might be considered too speculative. All that remained to ease the burden of proof of both legal injury and damage was for the Court to state that the fact of danage, the remaining element of legal injury, need be proved no

28. Id.

29. Id. at 268.

30. Id. at 264 .

31. 370 U.S. 690 (1962).

32. Id. at 700-01.

33. Id. at 700 (emphasis added).

The Court cited with approval the following conclusion of the court of appeals, which had in turn cited Bigelow, Eastman Kodak, and Story Parchment:

[W] here the plaintiff proves a loss, and a violation by defendant of the antitrust laws of such a nature as to be likely to cause that type of loss, there are cases which say that the jury, as the trier of the facts, must be permitted to draw from this circumstantial evidence the inference that the necessary causal relation exists. Id. at 697, quoting 289 F.2d 86, 90 (9th Cir. 1961) (footnote omitted). 
more definitely than the amount of damages. The Court did this six years later in Zenith Corp. v. Hazeltine Research, Inc. ${ }^{34}$

Zenith involved a claim that the plaintiff had been excluded from a number of foreign markets by illegal anticompetitive patent pooling. The district court, sitting without a jury, had awarded! almost $\$ 35$ million in treble damages. ${ }^{35}$ The court of appeals had reversed, emphasizing that Zemith had failed to show the fact of damage. ${ }^{36}$ The Suprenie Court reversed the court of appeals, chastismg it for failing to "adhere to the teachings of Bigelow. . . and other cases dealing with the standard of proof in treble-damage actions." ${ }^{\text {"37 }}$ The Court held that the fact-finder may infer from evidence of a decline in "prices, profits, and values" that the wrongful acts of the defendant "had caused damage to the plaintiffs." 38 Thus, the Zenith opmion marked Supreme Court recognition of the appropriate use of the "less than certainty" standard of proof, first enunciated in Eastman Kodak, in fact of damage determinations.

This is not to suggest that the Court, by allowing plaintiffs to succeed on the basis of "inferences" and "speculation" of the fact of damage and the amount thereof, has removed from plaintiffs the burden of coming forward with the best proof possible under the circumstances of any given litigation. The Court has recognized, however, that in niany circumstances in which the violation alleged has made it difficult for a plaintiff to show the amount of damage suffered, it is equally difficult to "prove," in a stringent sense, legal mjury. Plaintiffs must still show a violation which might have had an impact on them, and must do the best they can under the circumstances to show what that impact was, but fact-finders are to be allowed to make just and reasonable inferences from the proof offered by both plaintiffs and defendants as to whether any injury has actually occurred. At the very least, the Court has made it clear that directed verdicts against plaintiffs on the basis of not having shown the fact of injury, and similarly founded summary judgments, will generally be inappropriate.

34. 395 U.S. 100 (1969).

35. This figure is cited in the court of appeals opinion, Hazeltine Research, Inc. v. Zenith Radio Corp., 388 F.2d 25, 28 (7th Cir. 1967). The district court opinion is reported, 239 F. Supp. 51 (N.D. Ill. 1965), but this figure is not stated in the opinion.

36. See Hazeltine Research, Inc. v. Zenith Radio Corp., 388 F.2d 25, 35-37 (7th Cir. 1967) ("The finding of the district court that Zenith had been injured . . . is clearly erroneous." Id. at 37).

37. 395 U.S. at 123.

38. Id. at 123-24 (eniphasis added). The Court also reiterated its Contintental Ore holding: 
This analysis of the Supreme Court's decisions on the burdens of proving each element of an antitrust plaintiff's cause of action has not been fully adopted by the lower federal courts. ${ }^{39}$ Indeed, the "hornbook law" on the subject does not recognize an eased burden of proof for any element but the amount of damages. ${ }^{40}$ Defendants thus continue to prevail in civil damages cases for the stated reason of plaintiffs' insufficient proof of injury. ${ }^{41}$

It appears, however, that several of the courts which have ruled for defendants on the grounds of plaintiffs' failures of proof have done so not for the stated reason of failure to prove legal injury, but because the courts do not believe that the plaintiff has presented the best available evidence of injury. ${ }^{42}$ For example, in Cecil Corley Motor Co. v. General Motors Corp., ${ }^{43}$ a district judge granted a motion for judgment n.o.v. in a case involving breach of contract and RobinsonPatman, Sherman, and Dealers Day in Court Act claims. The court found the plaintiff's evidence of both liability and damages, which was based on expert testimony as to the plaintiff-dealer's "variable net profit," "wholly insufficient." 44 The court expressed particular dissatisfaction with the plaintiff's method of proof, noting that the plaintiff had the means to calculate a reasonably certain net profit figure instead of relying on expert estimates. ${ }^{45}$

[T] he injury alleged by Zenith was precisely the type of loss that the claimed violations of the antitrust laws would be likely to cause. The trial court was entitled to infer... that the necessary causal relation between the pool's conduct and the claimed damage existed. Id. at 125 (emphasis added).

39. See text accompanying notes 47-85 infra.

40. See, e.g., P. AREedA, Antitrust Analysis II 159 (e) at 70 (2d ed. 1974) ("[t]he courts seem to require more proof of the fact of injury than of the quantum of injury ...." quoting Story Parchment Co. v. Paterson Parchment Paper Co., 282 U.S. 555, 562 (1931)); $16 \mathrm{~N}$ J. VON Kalinowski, ANTITRUST LAWS aNd TRADE Regulation § 115.02[2], at 115-32 (1974) ("Thus, while the fact of injury must be established with absolute certainty, the amount of damage requires a lesser degree of proof.") (emphasis in original).

Professor Areeda later acknowledges, in discussing standing to sue, that causation may be inferred, citing Bigelow v. RKO Radio Pictures, Inc., 327 U.S. 251, 264 (1946), quoted in the text accompanying note 23 supra. P. AREEDA, supra II 160 (d) at 74 . On standing, see notes 86-115 infra and accompanying text.

41. See, e.g., Cecil Corley Motor Co. v. General Motors Corp., 380 F. Supp. 819 (M.D. Tenn. 1974); Hallmark Industry v. Reynolds Metal Co., 1971 Trade Cas. II 73,409 (N.D. Cal. 1970), aff'd, 489 F.2d 8 (9th Cir. 1973), cert. denied, 417 U.S. 932 (1974).

42. For other examples, see McCaskill v. Texaco, Inc., 351 F. Supp. 1332 (S.D. Ala. 1972), aff'd sub nom., Harrelson v. Texaco, Inc., 486 F.2d 1400 (5th Cir. 1973); Peter v. Union Oil Co., 328 F. Supp. 998 (C.D. Cal. 1971).

43. 380 F. Supp. 819 (M.D. Tenn. 1974).

44. Id. at 826 .

45. This Court must note that the plaintiff had in its possession the means 
Insofar as failure to produce the "best evidence" is the basis for holdings such as this, the lower courts are indeed reflecting the Supreine Court's views. The purpose of the Court's easing of the burdens of proof was to relieve plaintiffs of the difficulties caused by defendants' actions, not to encourage plaintiffs' selective use of evidentiary techniques. ${ }^{46}$ Yet each time a court repeats the seemingly outdated distinction between the degree of proof necessary to show injury and that necessary to show the amount of damages, it admittedly becomes harder to argue for the elimination of the distinction in subsequent cases.

\section{B. Burden of Proof Distinctions in the Lower Courts}

As noted above, many lower courts still at least pay lip service to the principle that the standard of proof for showing legal injury is considerably more rigorous than the standard for showing the annount of damages sustained. ${ }^{47}$ But there is a recognizable judicial trend toward applying the reasoning set forth in the Supreme Court cases discussed above to determinations of both the fact of injury and annount of damages. The "fact of damage" was clearly the focus of a recent Eiglth Circuit decision, Agrashell, Inc. v. Hammons Products Co. ${ }^{48}$ a case that presented an antitrust counterclaim to a patent infringement suit. In discussing the argument that the counterclaimant had "failed to prove the fact of damage resulting froin the use of the contracts,"49 the court went to great length to show the shortcomings of the plaintiff's damage presentation. It first explained its "hesitancy to allow a jury to assess damages" 50 on the theory offered, and quoted from a 1966 Eighth Circuit case in which it held that "[b]efore a party is entitled to recover treble damages he must be able to plead and prove actual nonetary injury . . . "ri But the court then examined the impact of

with which to calculate, with reasonable certainty, a net profit figure as to Pontiac automobiles. It could have used the stock record cards ... in order to establish and compute the average gross profit on new Pontiac units for each year. Expenses could then have been proportionalized in accordance with the proportion of actual Pontiac sales . . . However, plaintiff chose instead to go to the jury with less than the best available evidence on dainages.

Id. at 858 (footnote omitted).

46. See, e.g., Bigelow v. RKO Radio Pictures, Inc., 327 U.S. 251, 266 (1946), quoted in text accompanying notes 23-24 supra.

47. See, e.g., Farmington Dowel Prod. Co. v. Forster Mfg. Co., 421 F.2d 61 (1st Cir. 1969); Knutson v. Daily Review, Inc., 383 F. Supp. 1346 (N.D. Cal. 1974); Peter v. Union Oil Co., 328 F. Supp. 998 (C.D. Cal. 1971).

48. 479 F.2d 269 (8th Cir.), cert. denied, 414 U.S. 1022 (1973).

49. Id. at 280 (emphasis added).

50. Id. at 283.

51. Id., quoting American Infra-Red Radiant Co. v. Lambert Indus., Inc., 360 F.2d 977, 995-96 (8th Cir.), cert. denied, 385 U.S. 920 (1966). 
the Supreme Court decisions on the plaintiff's burden of proving some damage, emphasizing the Court's consistent reminders that "an antitrust violator may not properly complain about damage proof vagaries when such ambiguity results from the illegal act itself," the counterclaimant could not be said as a natter of law to have failed to show "the fact or quantum of damage with sufficient clarity."53

The Sixth Circuit also seems to have recognized an easier standard of proof for the fact of dannage. In Gaines $v$. Carrollton Tobacco Board of Trade, Inc. ${ }^{54}$ a restraint of trade action against a tobacco marketing board which had restricted plaintiffs' participation in sales activities, the court found that "this record discloses that plaintiffs clearly suffered damages in both years at issue and that the record affords a basis for computation of those damages." 55 Six reasons were set forth in support of these conclusions, ${ }^{50}$ but the opinion unfortunately does not make clear on which ones the court was relying to evaluate the proof of the fact of injury. A less stringent standard clearly was being adopted, however: the court found that evidence that the defendant had limited plaintiffs' sales space "serves to argue strongly as a matter of common sense that some damage must have resulted." "57 The court seems to have held that proof of the violation, without more, constituted proof of some damage. ${ }^{58}$

Other courts of appeals have focused more clearly on the causation element of the legal injury determination. For example, in Klinger $v$. Baltimore \& Ohio Railroad Co. ${ }^{59}-$ a rare decision involving section 10 of the Clayton Act (which prohibits the trading of securities without competitive bidding among common carriers having interlocking directorates) ${ }^{80}$ - the Second Circuit seemed to excuse the plaintiff altogether

\footnotetext{
52. 479 F.2d at 283.

53. Id.

54. 496 F.2d 284 (6th Cir. 1974).

55. Id. at 286.

56. Id. at $286-87$.

57. Id. at 286.

58. See notes 69-79 infra and accompanying text for the view of the Fifth Circuit.

59. 432 F.2d 506 (2d Cir. 1970).

60. Section 10 of the Clayton Act, 15 U.S.C. $\$ 20$ (1970), provides (in pertinent
} part):

No common carrier engaged in commerce shall have any dealings in securities, supplies, or other articles of commerce, or shall make or have any contracts for construction or maintenance of any kind, to the amount of more than $\$ 50,000$, in the aggregate, in any one year, with another corporation, firm, partnership, or association when the said common carrier shall have upon its board of directors or as its president, manager, or as its purchasing or selling officer or agent in the particular transaction, any person who is at the same time a director, manager, or purchasing or selling officer of, or who has any substantial interest in, such other corporation, firm, partnership, 
from showing causation. The case arose when stockholders of the Reading Company brought suit to recover damages allegedly suffered by the coinpany as a result of the sale to the $B$ \& $O$ of Reading's ownership interest in a Philadelphia produce terminal, a sale which plaintiffs alleged violated section 10 . The district court awarded $\$ 1.6$ million. Although the court of appeals reversed and reinanded the case with instructions to dismiss the complaint, in part because no actual damages had been shown, it articulated its view that the burden of proof on the issue of causation should be on the wrongdoer. ${ }^{31}$ The court thus relieved the plaintiff entirely of the burden of proving causation. The concluding language of the opinion also seems to suggest that the less stringent burden would apply to proof of injury in fact. "As we find that $\mathrm{B} \& \mathrm{O}$ has sustained the burden of persuading us that there would have been no other bidders and that, if there had been, they would have offered less than $B$ \& $O$ actually paid, we find it not liable to Reading." 2

The tendency to stress the causation element of the legal injury determination, and thus to allow relaxed burdens of proof, also is reflected in a Third Circuit case. In Rea v. Ford Motor Co., ${ }^{6: 3}$ a disgruntled dealer charged Ford with restraint of trade and price fixing. The court expressly rejected an easier burden of proof of legal injury with respect to the restraint of trade allegation by stressing the fact of damage element, ${ }^{64}$ but the opposite tack was taken in its discussion

or association, unless and except such purchases shall be made from, or such dealings shall be with, the bidder whose bid is the most favorable to such common carrier, to be ascertained by competitive bidding under regulations to be prescribed by rule or otherwise by the Interstate Commerce Commission.

61. The court provided the following discussion:

Plaintiffs argued that it is too much to ask them to prove, first, the existence of potential bidders, and second, that a hypothetical buyer would have offered more than was actually paid, as it is defendant's wrongdoing that created the difficulties of proof. Although the cases plaintiffs cite in support of the proposition that defendants may not escape liability by subjecting plaintiffs to impossible burdens of proving injury, causation, and damages in fact are almost exclusively concerned with proof of damages, not causation, see e.g.. Bigelow v. RKO Radio Pictures, Inc., . . we think the principle enunciated therein is sound. It is elementary that the wrongdoer shall bear the risk of the uncertainty which his own wrong has created .... But we do not accept plaintiff's suggestion that the proper remedy is to dispense with proof of causation entirely. Rather, we think that the proper resolution is to require the wrongdoers to bear the burden of proof on the issue of causality. 432 F.2d at 516 (emphasis added).

62. Id. Judge Hays dissented from Chief Judge Lumbard's opinion in Klinger, urging that the absence of competitive bidding was per se injurious, and that the Supreme Court decisions discussed in the text accompanying notes 12-46 stlpra were therefore "directly applicable." 432 F.2d at 521.

63. 497 F.2d 577 (3d Cir.), cert. denied, 419 U.S. 868 (1974).

64. Id. at 589 . 
of the price-fixing claims. Ford had contended that the plaintiff's testimony failed "to establish that its alleged antitrust violation caused the alleged loss of revenue." Brs But the court found that argument an "unduly restrictive view of causation under the facts of the case," held that " $[t]$ here is sufficient evidence that the price-fixing agreement .. . would tend to injure plaintiff's business" and thus to "find that [plaintiff] was injured in its business . . . and is entitled to recover treble damages." ${ }^{\circ}$ Only after reaching this conclusion did the court consider the defendant's objections to the amount of damages awarded, dismissing them with a citation to Bigelow. ${ }^{08}$

The Fifth Circuit also inay have recognized the easier standard of proof of legal injury, although the cases are ambiguous. In Hobart Brothers Co. v. Malcolm T. Gilliland, Inc., ${ }^{69}$ the court stressed the easier burden of showing causation. The case presented an antitrust counterclain to a suit originally brought by a manufacturer agamst a distributor. Affirming a district court judgment for $\$ 276,000$ on the counterclaim, the court of appeals discussed several issues, including distributor Gilliland's need to show "that its injury was caused by [Hobart's] conduct prohibited by the anti-trust laws." noted that "[f]rom the surrounding circuinstantial evidence, the triers of fact were entitled to infer the necessary causal relationship between Hobart's disparagement as used to enforce the illegal territorial restraints and Gilliland's damages." 11

A year later, however, in Terrell v. Household Goods Carriers' Bureau, ${ }^{72}$ Judge Goldberg cited only Story Parchment in holding that "[b]oth the fact of damage, or causation, and the amount of damage are questions of sufficiency of the evidence, though the certainty of proof required on each issue differs." 73

Most recently, in Copper Liquor, Inc. v. Adolph Coors Co., ${ }^{74}$ and

65. Id. at 591 .

66. $1 d$.

67. Id. at 591-92.

68. Id. at 592. Deaktor v. Fox Grocery Co., 475 F.2d 1112 (3d Cir.), cert. denied, 414 U.S. 867 (1973), appears to reach the same conclusion, but does not cite any precedent.

69. 471 F.2d 894 (5th Cir.), cert. denied, 412 U.S. 923 (1973).

70. Id. at 901 .

71. Id. See Zenith Radio Corp. v. Hazeltine Research, Inc., 395 U.S. 100, 125 (1969).

72. 494 F.2d 16 (5th Cir.), petition for cert. dismissed, 419 U.S. 987 (1974).

73. Id. at 20. One page later in the same opinion, however, the court noted that "there is no neat dividing line between the issues of liability and damages" in an antitrust civil action. Id. at 21.

74. 506 F.2d 934, rehearing denied, 509 F.2d 758 (5th Cir. 1975). 
Shumate \& Co. v. National Association of Securities Dealers, ${ }^{75}$ the old distinctions again were recognized. ${ }^{76}$ But the decisions are ambiguous. In Copper Liquor, for example, the court also acknowledged that "[p]roving mjury in fact and proving damages are obviously similar tasks in an action of this nature." "I7 In a subsequent opinion denying rehearing, the court did not succeed completely in clarifying its earlier holding. "Reasonable estimates" of damages are appropriate, the court held, "once the plamtiffs demonstrate actual injury. But the mere proof of an antitrust violation, without more, cannot support an award of damages."78 In so holding, the Fifth Circuit seems to have been focusing on proof of the amount of damages, not proof of the fact of damage. If the statement is read as relating to the fact of damage, the Circuit's position would conflict with that of the Sixth Circuit. ${ }^{79}$

The somewhat confused decision of the Third Circuit in Rea v. Ford Motor $\mathrm{Co}_{0}{ }^{80}$ which apparently requires greater proof to recover for restraint of trade than for price-fixing, sheds some light on the question of whether proof of violation establishes the fact of damage. Any plaintiff who has shown that he has standimg and who has paid illegally fixed minimum prices, a per se violation, has established some injury. ${ }^{81}$ In soine situations, proof of a restraint of trade may also constitute proof of some injury. ${ }^{82}$ But the fact that one has standing as an established and active distributor, for example, does not in and of itself automatically establish the fact that one has been injured by an alleged conspiracy in a

75. 509 F.2d 147 (5th Cir. 1975).

76. The following excerpt is illustrative:

The general rules relating to antitrust damages are easy to state, but difficult to apply. It is said that, once a plaintiff in a private antitrust action has proved that the defendant violated the law and that this violation caused him injury in fact, the plaintiff is held to a less rigid standard of proof with respect to the actual dollar amount of his damages. Copper Liquor, Inc. v. Adolph Coors Co., 506 F.2d at 953.

77. $I d$. at 954 .

78. 509 F.2d at 759. The case was remanded for a determination of additional evidence on the plaintiff's injury with the observation that "the plaintiff faces a substantial hurdle on remand in proving injury." $506 \mathrm{~F} .2 \mathrm{~d}$ at 954.

79. See Gaines v. Carrollton Tobacco Bd. of Trade, 496 F.2d 284 (6th Cir. 1974), discussed at notes 54-58 supra and accompanying text.

80. 497 F.2d 577 (3d Cir.), cert. denied, 419 U.S. 868 (1974). See notes 63-68 supra and accoinpanying text.

81. This is probably the point the Sixth Circuit was making in Gaines v. Carrollton Tobacco Bd. of Trade, 496 F.2d 284 (6th Cir. 1974), when it stated that "the antitrust violation involved . . . is of the per se variety . . . in relation to which dainages may be found on proofs which represent less than absolute certainty." Id. at 286. See notes 8698 infra and accoinpanying text.

82. Cf. Gaines v. Carrollton Tobacco Bd. of Trade, 496 F.2d 284, 286 (6th Cir. 1974). See notes 54-58 supra and accompanying text. 
restraint of trade which did not result in an overcharge. ${ }^{83}$ As was recently observed in Knutson v. Daily Review, Inc. ${ }^{84}$ (a case in which a newspaper distributor challenged a publisher's restriction on the maximum rate which could be charged for his newspapers), "the fact of damage in a case charging maximum price fixing is not automatic once the violation is established as it might be where plaintiffs have been overcharged by a monopolist or by a conspiracy to fix minimum prices." ${ }^{\text {.5 }}$

\section{II. "Pass-ON" and Damages}

\section{A. The Hanover Shoe Standard}

The Supreme Court's decision in Hanover Shoe, Inc. v. United Shoe Machinery Corp. ${ }^{80}$ constitutes a sixth Supreme Court statement on the "damages" issue. Although the decision has often been relied upon in a standing context, it is important to recognize that it actually addressed the passing-on doctrine ${ }^{87}$ as a defense to the plaintiff's attempt to show legal injury. The case arose as a result of the defendant's refusal to sell rather than lease its machinery to the plaintiff shoe manufacturer. The defendant's "lease-only" policy had clearly cost the plaintiff more than outright purchase would have cost him. Nevertheless, the defendant claimed that the plaintiff had "suffered no legally cognizable injury" 88 because any excess costs had been passed on by the plaintiff to others, that is, to the purchasers of its products.

The holding of the case should be read as a statement concerning both proof of legal injury and the amount of damages suffered:

We think it sound to hold that when a buyer shows that the price paid by him for materials purchased for use in his business is illegally high and also shows the amount of the overcharge, he has made out a prima facie case of injury and damage within the meaning of $\S 4 . .^{89}$

As the italicized portion of this statement indicates, the Court was clearly holding that, in a case alleging an illegal overcharge, legal imjury is sufficiently established by the proof of the violation to allow the case to go to the jury. "As long as the seller continues to charge the illegal

83. Cf. Copper Liquor, Inc. v. Adolph Coors Co., 506 F.2d 934, rehearing denied, 509 F.2d 758 (5th Cir. 1975). See text accompanying note 78 supra.

84. 383 F. Supp. 1346 (N.D. Cal. 1974).

85. Id. at 1379.

86. 392 U.S. 481 (1968).

87. For a general discussion of the passing-on defense see $16 \mathrm{~N} \mathrm{~J}$. von KaLINowSEI, supra note $40, \S 109.03$.

88. 392 U.S. at 487.

89. Id. at 489 (emphasis added). 
price, he takes from the buyer more than the law allows. At whatever price the buyer sells, the price he pays the seller remains illegally high "90

The Court's limitation of the pass-on defense was based on a recognition of the difficulties of proof that plaimtiffs would face and on a policy decision that these difficulties should be avoided. The concern with the difficulties of proof which face antitrust plaintiffs is, of course, the same concern as that reflected in the Supreme Court cases discussed in the first part of this Article. ${ }^{91}$ The Court was "not impressed with the argument that sound laws of economics require recognizing this defense" and found that the "nearly msuperable difficulty of demonstrating that the particular plaintiff could not or would not have raised his prices absent the overcharge or maintained the higher price had the overcharge been discontinued" would make plaintiffs' recoveries extremely difficult, if not impossible. ${ }^{22}$ The availability of the defense would thus result in "[t]reble-damage actions . . . often requir[ing] additional long and coinplicated proceedings involving massive evidence and complicated theories." ${ }^{33}$ A desire to avoid these delays - a policy choice-led the Court to prohibit the use of the pass-on defense as a response to most attempts to prove legal injury.

In concluding its discussion of the pass-on issue, the Court prescribed a narrow exception in which pass-on might be raised in this determination. At least where "no differential can be proved between the price unlawfully charged and some price that the seller was required by law to charge, establishing dainages might require a showing of loss of profits to the buyer." ${ }^{44}$ By creating this exception, the Court admitted that there would be some cases in which passing-on might be relevant to a legal imjury determination. Implicit in the Court's language, however, is the realization that these few situations would require a determination of what facts had been proved. The pass-on defense, therefore, would not prevent the case from reaching a jury.

Hanover Shoe does not preclude the consideration of pass-on evidence witl respect to determination of the anount of damages. Indeed, the closing pages of the opinion, which address mitigation of the plaintiff's recovery as a result of certain taxation and financing matters, reflect a realization that complicated proofs of the amount of dain-

90. Id.

91. See note 12 supra and accompanying text.

92. 392 U.S. at 492.

93. Id. at 493.

94. Id. at 494 . 
age must be suffered. Therefore, the broadest language of Justice White's opinion, to the effect that "treble damage actions would often require additional long and complicated proceedings" if the defense were allowed, ${ }^{95}$ should be confined to the context of a defense to legal injury. Expanding this language to the proof of damages issue would eviscerate the "injury in business or property" standard of the statute. ${ }^{96}$ Of course, the eased burden on plaintiffs to show the aniount of their dainages ${ }^{27}$ may linit the value of the availability of the pass-on defense to defendants in the determination of this final element of recovery. But the common procedure of bifurcating a trial into liability and damage deternination phases indicates that it would be appropriate to permit jury consideration of the pass-on defense at the danıages stage of the case while witholding the defense from the jury in the liability phase.

As a policy choice, the Supreme Court's decision to limit the use of the pass-on defense nuay be criticized. If one posits that a defendant may ultiniately be able to show that no coinpensable damage actually has been suffered, it seems appropriate to reach this conclusion at the earliest possible point in the proceednigs. The policy decision set forth in Hanover Shoe, however, like that made in the quimtet of Suprenie Court cases cited earlier ${ }^{08}$ reflects a sympathy to plaimtiffs which is necessary (in the Court's view) to preserve the iniportant role of private antitrust enforcement in our economy, and a concomitant judicial unwillingness to make a preniature determination on what are essentially factual issues. Defendants forced to go through a trial proceeding will clearly pay a price-which may ultiniately be passed on to society at large-but it is a price that the Suprene Court, at least, believes should be paid in order to maintain the viability of the treble damages action.

\section{B. Lower Court Pass-On Cases}

Hanover Shoe has been raised inost often as a bar to antitrust plaintiffs' standing. ${ }^{09}$ Of course, to deny a plaintiff standing on the basis of an assertion of the pass-on defense is inconsistent witl the analysis presented above. There is, however, nothing logically incon-

95. Id. at 493 .

96. 15 U.S.C. $\$ 15$ (1970).

97. See notes 12-19 supra and accompanying text.

98. See note 12 supra.

99. See, e.g., Travis v. Fairnount Foods Co., 346 F. Supp. 679 (E.D. Pa. 1972); Balmac, Inc. v. American Metal Prod. Corp., 1972 Trade Cas. 174,235 (N.D. Cal. 1972); Philadelphia Housing Authority v. American Radiator \& Standard Sanitary Corp., 50 F.R.D. 13 (E.D. Pa. 1970), aff'd sub nom. Mangano v. American Radiator \& Standard Sanitary Corp., 438 F.2d 1187 (3d Cir. 1971). 
sistent in considering the issue in both the standing and liability phases of a trial, so that those cases which discuss pass-on in the context of the standing issue need not be seen as precluding application of the doctrine at later stages.

Several post-Hanover lower court cases have presented analyses of the pass-on defense consistent with that suggested. here. The most authoritative opinions are those of the courts of appeals in In re Western Liquid Asphalt Cases, ${ }^{100}$ and West Virginia v. Chas. Pfizer \& Co. ${ }^{101}$

The In re Western Liquid Asphalt complaints alleged a conspiracy to submit rigged bids, to allocate and stabilize the relevant market, and otherwise to fix prices and eliminate competition. Plaintiffs both bought asphalt directly from the defendants and contracted for construction projects in which asphalt was used. Relying heavily on Hanover Shoe, the district court granted summary judgment for the defendants on those claims brought by plaintiffs only as ultimate users on the ground that, as a matter of law, the plaintiffs had no cause of action to recover for their indirect purchases. ${ }^{102}$

The Ninth Circuit reversed. Judge Carter, writing for himself and Judges Goodwin and Ferguson, noted that "Hanover Shoe was concerned with a defense to liability, not with standing, and not with apportionment of damages." 103 The court also noted that the district court had found, on the basis of affidavits, that liability-legal injury from a violationcould be shown, but had denied standing apparently because of concern over proof of damages. ${ }^{104}$ Noting that the Supreme Court had suggested, with respect to the liability issue, that "there might be situations ... where the considerations requiring that the passing-on defense not

100. 487 F.2d 191 (9th Cir. 1973), cert. denied, 415 U.S. 919 (1974). The Western Liquid Asphalt decision resolved the standing issue in cases brought by users of asphalt. The court provided a comprehensive discussion of the proper use of pass-on. The Ninth Circuit previously had briefly commented upon Hanover Shoe in Gray v. Shell Oil Co., 469 F.2d 742 (9th Cir. 1972), cert. denied, 412 U.S. 943 (1973), in which Judge Kilkenny distinguished the station-lessee versus supplier situation before him from the facts presented in Hanover Shoe. His opinion indicated, however, a view of Hanover Shoe consonant with the analysis provided in Western Liquid Asphalt:

The facts in Hanover Shoe . . , upon which appellants rely, bear no similarity to ours. There, the court held, that Hanover proved injury and the amount of its damages for the purposes of its treble damage suit when it produced evidence that United had overcharged it during the damage period and demonstrated the amount of the overcharge. Here, there is no proof of an overcharge. 469 F.2d at 750 (emphasis in original).

101. 440 F.2d 1079 (2d Cir.), cert. denied, 404 U.S. 871 (1971).

102. 350 F. Supp. 1369 (N.D. Cal. 1972).

103. 487 F.2d at $198-99$.

104. See id. at 196 n.5. 
be permitted in this case would not be present," ${ }^{105}$ the court of appeals observed:

The [Supreme] Court thus left open for future decision cases in which the passing on of an illegal overcharge might be more readily demonstrable. Ours is such a case. Based on affidavits, the district court assumed that appellants could so show. ${ }^{106}$

The court drew the distinction between proving liability and proving damages in a footnote to this statement. ${ }^{107}$ According to the Ninth Circuit, the Supreme Court in Hanover Shoe had been focusing only on the possible difficulties of proving liability, which was not at issue in the case before the court of appeals. ${ }^{108}$ The court of appeals thus recognized that the Supreme Court's Hanover Shoe policy judgment to limit the raising of passing-on as a defense to liability did not also preclude consideration of complex proofs at the damages phase of a trial.

In West Virginia v. Chas. Pfizer \& Co., ${ }^{109}$ the Second Circuit discussed the pass-on issue in the context of a challenge to the distribution of a settlement fund. The recoveries of soine wholesaler members of the plaintiff class had been limited in the settlement to $\$ 3$ nillion "nuisance value"; several of these class members appealed the approval of the settlement, contending that they were entitled to the entire $\$ 37$ million award made to the consunner class. The court of appeals rejected their challenge, however, recognizing the "result orientation" of

105. Hanover Shoe, Inc. v. United Shoe Mach. Corp., 392 U.S. 481,494 (1968).

106. 487 F.2d at 196 (footnote omitted).

I07. Id. at 196 n.5.

108. The district court felt that the complexities of proof of damages, mentioned in Hanover Shoe, supra, were present in this case:

It has never been thought that an antitrust violation is irremediable because done on a grand scale. The Supreme Court spoke of "virtually unascertainable figures" associated with proof that a particular intermediary "could not or would not have raised his prices absent the overcharge or maintained the higher price had the overcharge been discontinued." This was in relation to the liability issue, which in our case is obviated by the district court's assumption that appellants could prove an illegal overcharge which was passed on to them. We have elsewhere mentioned the relaxed proof on the damages issue in antitrust cases. Id. (emphasis in original) (citation omitted).

The ambiguous "elsewhere" in the final sentence of the quotation apparently was referring to the Ninth Circuit's holding in Mulvey v. Samuel Goldwyn Prods., 433 F.2d 1073 (9th Cir. 1970), cert. denied, 402 U.S. 923 (1971), which is discussed later in the opinion. $487 \mathrm{~F} .2 \mathrm{~d}$ at 199. At that point, the court held that "the problems of damages and causation are questions of fact for the jury. Evidence that a price advantage was 'passed on, at least in part' to plaintiff's competitor, inter alia, provides sufficient substance for the question of causation to be submitted to the jury." Id. In short, insofar as the pass-on defense is relevant to the legal injury issue, it presents an issue of fact, not an issue of law. It is not a basis for preventing an action from reaching the jury.

109. 440 F.2d 1079 (2d Cir.), cert. denied, 404 U.S. 871 (1971). 
the Supreme Court in private civil damage litigation ${ }^{110}$ and the Court's emphasis on the importance of such actions to the American economy. The court distinguished the case at hand from Hanover Shoe because the pass-on doctrine was being used affirmatively in an attempt to award damages to those who ultimately paid higher prices because of the collusive acts, instead of as a defense to permit the wrongdoers to escape liability altogether. It recognized that use of the doctrine in such circumstances would actually encourage (rather than frustrate) private treble-damage claims. ${ }^{111}$ The Second Circuit thus affirmed the district court's recognition of the appropriateness of the pass-on theory in the determination of the amount of damages recoverable by a specific plaintiff. ${ }^{112}$

110. Id. at 1087. The court cited Minnesota Mining \& Mfg. Co. v. New Jersey Wood Finishing Co., 381 U.S. 311 (1965), as an example of the Supreme Court's resultoriented approach. 440 F.2d at 1087.

111. Id. at 1088 .

112. Two district court opinions have also adopted the view that Hanover Shoe reserves resolution of the pass-on issue until the ultimate factual determination. In Boshes v. General Motors Corp., 59 F.R.D. 589 (N.D. Ill. 1973), Judge Decker denied both a defense motion to dismiss and a plaintiff's motion for certification of a class in a price-fixing and monopolization action brought on behalf of all purchasers of General Motors automobiles between 1965 and 1968. In rejecting an argument that Hanover Shoe established a test of privity for standing, the court recognized that pass-on would be a question for a jury in the ultimate determination of the amount of damages suffered:

For example, a jury finding that an overcharge had been passed-on, particularly by a party in contractual privity with an alleged antitrust violator, would preclude relitigation on the same issue by the "passing-on" party (e.g. the initial purchaser) who is higher up in the distributive chain. 59 F.R.D. at 596 n.9.

This observation was based on what this author believes to be a proper view of the policy underlying Hanover Shoe:

There are two clearly discernable policy statements made by Justice White in the Hanover Shoe opinion. The first is that under the circumstances of the case, the trial court was correct in refusing to consider evidence that, as a practical and economic matter, was purely subjective and speculative ....

The second policy statement offered in Justice White's opinion is that private enforcement of the antitrust laws should not be frustrated by permitting unduly complicated and speculative defenses when to do so might leave a burden of enforcement on those least likely to accept it. Id. at 594.

Four months after the Boshes decision, District Judge Blumenthal decided In re Master Key Antitrust Litigation, 1973-2 Trade Cas. II 74,680 (D. Conn. 1973), rejecting the defendant's Hanover Shoe-based "standing" argument. The court noted that Hanover Shoe "rejected a proposed pass-on defense in order to ensure that those who violated any antitrust laws did not escape liability through a multiplication of legal complexity," $i d$. at 94,978 , and thus rejected defendants' argument that since plaintiffs were not in contractual privity with them, the case must be dismissed. "The radical extent" of defendants" stretching of the Hanover Shoe decision, Judge Blumenthal found, "is seen when one recalls that Hanover denied a defense which was offered after plaintiffs had put in their proof in a long and complex trial. Here defendants seek to use that decision to shut off plaintiffs' case entirely and prevent them from going to trial at all." Id. at 
Despite the analysis presented above, there is a considerable body of precedent which applies Hanover Shoe to the standing issue. But nost of these cases explicitly or implicitly accept the premise that Hanover Shoe presented a defense to liability. ${ }^{113}$ The cases then develop their rejection of standing by analogy. But these decisions fail to recognize the direct holding of Hanover Shoe and give insufficient weight to the policies established by the Supreme Court in both Hanover Shoe and a number of other civil damages antitrust cases. ${ }^{114}$ As noted above, there is nothing logically wrong with the proposition that, as a policy matter, standing should be denied those who will be unable ultinately to show damagcs. But this policy has been rejected by the Supreme Court in favor of a policy of allowing plaintiffs to reach the jury. The cost to society from this pohicy choice may be substantial; certainly, the costs to defendants cannot be denied. But a balance has been struck, at least for the moment, on the basis of a judgment that those costs do not outweigh the benefits to the economic system of allowing treble damage actions to survive preliminary motions. Until this policy is modified by the Supreme Court, attempts to use the pass-on defense in such pretrial situations should be rejected.

\section{Measures of Damage Amounts}

\section{A. Methods of Proof: Theory}

We turn now to more concrete questions which relate to the ultimate questions of proof. The amount of damages will always, of course, be an issue for the trier of fact, be it judge or jury. However, there is a hidden benefit in choosing a jury over a judge in a treble damages action, because of the eased standards of proof peculiar to these actions. In a treble damages case, a restrictive jury cliarge may provide the basis of an affirmance on evidence which might have been found too speculative-even under the eased standards-without it. For example, in Hobart Brothers v. Malcolm T. Gilliland, Inc., ${ }^{115}$ a jury

94,979. Thus, consideration of the pass-on possibility required further factual development by the parties. "It would be improper, and somewhat illogical, to decide on a pretrial motion for summary judgment that the plaintiffs could not prove their damages. Such a determination should await trial." Id.

113. See, e.g., Donson Stores, Inc. v. American Bakeries Co., 58 F.R.D. 481, 484-85 (S.D.N.Y. 1973); Philadelphia Housing Authority v. American Radiator \& Standard Sanitary Corp., 50 F.R.D. 13, 29-30 (E.D. Pa. 1970), aff'd, 438 F.2d 1189 (3d Cir. 1971) (per curiam).

114. See notes 9-10 supra and accompanying text.

115. 471 F.2d 894 (5th Cir.), cert. denied, 412 U.S. 923 (1973). 
verdict indisputably based on expert testimony, which in turn rested on some rather dubious assumptions, ${ }^{116}$ was affirmed. The jury had been instructed that it was "not bound nor concluded by the opinion testimony of any witness, expert or otherwise, and [the jury] should not consider any expert witness unless [it] found the facts on which that opinion is based are true." 117 The court of appeals believed this charge allowed for a conclusion that the jury had given sufficient weight to the testimony.

Benefit of the charge notwithstanding, however, a plaintiff must still present some "relevant data" from which "a just and reasonable estimate of the damage" can be drawn. ${ }^{118}$ Moreover, the damages shown inust be damages to the plaintiff's business or property. ${ }^{110}$ Several methods have been approved by the courts for establishing such damages. These methods are not exclusive; a plaintiff inay adduce evidence which supports several alternative theories, leaving the factfinder to decide which proof-and thus which theory-is more persuasive. ${ }^{120}$

The two "classic" tests are the before-and-after approach, entployed in Eastman Kodak Co. v. Southern Photo Materials Co., ${ }^{121}$ and the yardstick theory used by the Supreme Court in Bigelow v. RKO Radio Pictures, Inc. ${ }^{122}$ The before-and-after approach simply involves a showing of a plaintiff's profits before the alleged violation and a showing of the loss of profit thereafter. The yardstick theory involves the comparison of a plaintiff's profits with that of another firm or person similarly situated. ${ }^{123}$ Both theories have received extensive attention in the literature. ${ }^{124}$

116. The defendant objected to three assumptions underlying the plaintiff's experts' damage theory: (1) that the damages began on January 1, 1964, instead of September 1 , 1964, the date of a report constituting the first evidence of defendants' anticompetitive actions; (2) that plaintiff would have been able to sell all of the machinery at issue; and (3) that plaintiff's growth rate (and thus sales and profits) would have paralleled those of General Electric, its principal customer. Id. at 902-03.

117. Id. at 903.

118. Bigelow v. RKo Radio Pictures, Inc., 327 U.S. 251, 264 (1946). See notes 14 26 supra and accompanying text.

119. See GAF Corp. v. Circle Floor Co., 463 F.2d 752, 757-59 (2d Cir. 1972), petition for cert. dismissed, 413 U.S. 901 (1973).

120. See, e.g., South-East Coal Co. v. Consolidated Coal Co., 434 F.2d 767, 792-94 (6th Cir. 1970), cert. denied, 402 U.S. 983 (1971).

121. 273 U.S. $359,376-79$ (1927).

122. 327 U.S. 251, 264-66 (1946).

123. Net profits, not gross profits, are the relevant figure. See Peter v. Union Oil Co., 328 F. Supp. 998, 1003 n.6 (C.D. Cal. 1971) and cases cited therein.

124. See articles cited in note 6 supra. 
The traditional tests are most attractive in attempting to show profits which the plaintiff was precluded from earning as a result of a defendant's antitrust violations. In a case in which a plaintiff has been driven out of a marketplace, these damages may also include profits which would have been gathered for some period into the future had plaintiff remained in the market. A large number of cases in the last five years have addressed this "lost past and future profits" issue. ${ }^{125}$

Some authorities list the "use of experts" as a third method of proving damages. ${ }^{120}$ This is hardly a meaningful distinction, however, since experts are often called upon in developing evidence under the before-and-after or yardstick tests. What these writers probably intend to list as a third means of showing damages-and properly so-is projection and modeling. Employing these relatively recently developed techniques, experts can present models designed to show a variety of factors which might influence a firm in a specific marketplace. ${ }^{127}$ These projections and models have become increasmgly sophisticated, and have often been found persuasive by the courts, provided that the premises from which the expert develops his conclusion have been established in the evidence. ${ }^{128}$

125. E.g., Copper Liquor, Inc. v. Adolph Coors Co., 506 F.2d 934 (5th Cir.), rehearing denied, 509 F.2d 758 (5th Cir. 1975); Gaines v. Carrollton Tobacco Bd. of 'Trade, 496 F.2d 284 (6th Cir. 1974); Terrell v. Household Goods Carriers' Bureau, 494 F.2d 16 (5th Cir.), petition for cert. dismissed, 419 U.S. 987 (1974); Cornwell Quality Tools Co. v. C.T.S. Co., 446 F.2d 825 (9th Cir. 1971), cert. denied, 404 U.S. 1049 (1972); South-East Coal Co. v. Consolidated Coal Co., 434 F.2d 767 (6th Cir. 1970), cert. denied, 402 U.S. 983 (1971); Poster Exchange, Inc. v. National Screen Service Corp., 431 F.2d 334 (5th Cir. 1970), cert. denied, 401 U.S. 912 (1971); Farmington Dowel Prod. Co. v. Forster Mfg. Co., 421 F.2d 61 (1st Cir. 1969); Burton Supply Co. v. Wheel House Prod., Inc., 1974-2 Trade Cas. II 75,224 (N.D. Ohio 1974); C. Albert Sauter Co. v. Richard S. Sauter Co., 368 F. Supp. 501 (E.D. Pa. 1973); Treadway Companies v. Brunswick Corp., 364 F. Supp. 316 (D.N.J. 1973), rev'd and remanded for new trial sub. nom. NBO Indus. Treadway Companies v. Brunswick Corp., 523 F.2d 262 (3d Cir. 1975); Wall Prod. Co. v. National Gypsum Co., 357 F. Supp. 832 (N.D. Cal. 1973); N.W. Controls, Inc. v. Outboard Marine Corp., 333 F. Supp. 493 (D. Del. 1971).

126. Sec, e.g., $16 \mathrm{~N}$ J. von KALINowsKI, supra note 40, 1115.03 [3] at 115-79 (1974).

127. See, e.g., Lehrman v. Gulf Oil Corp., 500 F.2d 659 (5th Cir. 1974), cert. denied, 420 U.S. 929 (1975); cf. South-East Coal Co. v. Consolidated Coal Co., 434 F.2d 767 (5th Cir. 1970), cert. denied, 402 U.S. 983 (1971).

128. As Judge Goldberg stated in Terrell v. Household Goods Carriers' Bureau, 494 F.2d 16 (5th Cir.), petition for cert. dismissed, 419 U.S. 987 (1974), "[the expert] is allowed sone econonic imagination so long as it does not become fantasy." Id. at 25 . Sce Lehrman v. Gulf Oil Corp., 500 F.2d 659 (5th Cir. 1974), cert. denied, 420 U.S. 929 (1975); Farnington Dowel Prod. Co. v. Forster Mfg. Co., 421 F.2d 61 (1st Cir. 1969); Coleman Motor Co. v. Chrysler Corp., 376 F. Supp. 546 (W.D. Pa. 1974). See text accompanying notes $144-50$ infra.

Under the new Federal Rules of Evidence expert testimony is admissible even 
Measures of damages not easily classifiable into these three categories have also been allowed. For example, in C. Albert Sauter Co. v. Richard S. Sauter Co. ${ }^{129}$ an action alleging that one of the plaintiff's former employees had violated the Sherman Act by improperly diverting substantial busmess to his own firm, a jury award of $\$ 400,000$ was affirmed. Evidence showing damages of over $\$ 750,000$ had been admitted; the items contributing to this total included the plaintiff's payments to employment agencies made necessary by the defendant's hiring away of a large number of the plamtiff's employees and the plaintiff's cost of retraining new employees and of paying higher salaries to retain those personnel not attracted by defendant. These damages can only be classified under one of the established rubrics, the beforeand-after test, by expanding that test to include all costs which stem froin an antitrust violation. To do so, however, would stretch the test beyond recognition. The Sauter court, in any event, did not find classification a necessary prerequisite to the damage award. ${ }^{130}$

\section{B. Methods of Proof: Application}

When considering what method of proof is most appropriate in the circumstances of his case, counsel should recognize that these "tests" are actually classifications of general methods of proof. A variety of evidence may be adduced in support of each of the traditional tests.

For example, in Continental Baking Co. v. Old Homestead Bread Co., ${ }^{131}$ both the Old Homestead and Interstate baking compamies urged that Continental's private-label bread inarketing practices violated the Robinson-Patman Act. Each plaintiff used different evidence in the context of a before-and-after showing; the court of appeals affirmed awards of over $\$ 1$ inillion to Old Homestead and approximately $\$ 130$,000 to Interstate.

Old Homestead proved it had been driven out of business by Continental Baking's illegal practices. Claiming damages equal to its

without the establishment of a factual basis in the record. See FED. R. Evid. 703. The evidence will not necessarily be found persuasive, however.

129. 368 F. Supp. 501 (E.D. Pa. 1973).

130. Woods Exploration \& Producing Co. v. Aluminum Co. of America, 438 F.2d 1286 (5th Cir. 1971), cert. denied, 404 U.S. 1047 (1972), provides another example of "nonclassifiable damages." An award of $\$ 142,759$ to one plaintiff was reinstated by the appellate court after the district court had granted a motion for judgment n.o.v. The appellate court found the award "clearly supported by the evidence," $i d$. at 1309 , which included a showing of the cost of pipe purchased by plaintiff but unusable because of defendant's anticompetitive action, the expense of constructing a second pipeline, and the plaintiff's intention and preparedness to construct an extraction plant.

131. 476 F.2d 97 (10th Cir.), cert. denied, 414 U.S. 975 (1973). 
projected lost profits less the going-concern value of the firm at the time of its dissolution, Old Homestead first showed its total dollar volume of sales for the relevant period. It then presented evidence to show that Continental's activities had resulted in a ten percent reduction in the wholesale price of bread. The jury award reflected approximately ten percent of Old Homestead's sales. ${ }^{132}$

Interstate employed another method of proof. First, the company introduced its routemen's weekly charts, which showed deliveries to each customer before and after the challenged activities had begun. Interstate then produced a witness who testified as to the percentage increase in profits the firm would have obtained with each $\$ 1000$ increment in weekly sales. This expert testified that the additional profits would anount to over forty percent of sales; the jury award was based on an apparent determination that twenty percent of sales would have become profits. The court of appeals found sufficient evidence to uphold the jury verdict. ${ }^{133}$

The yardstick method can also be applied in different ways. Bigelow presented a classic use: a theater's profits were compared to those of a similarly situated neighbor. In Lehrman v. Gulf Oil Corp., ${ }^{134}$ another approach was employed. The case arose from a service station owner's allegations that Gulf's complicated pricing system had violated the Sherman Act. The case had come before the appellate court once before; ${ }^{135}$ the instant opinion focused only on the dannages aspect of the case. Judge Gewin noted that "Lehrman's method of proof encompassed elements of both the before and after theory and the yardstick theory," 138 in that sales volume levels were shown with a before and after approach, but expenses by a yardstick comparison with three

132. The ten percent was applied to Old Homestead's sales less commissions.

133. See 476 F.2d at 110-13. Counsel considering the use of the before-and-after test should recognize that the test contemplates evidence in the form of normal business records compiled before the start of litigation. A district court case, Knutson v. Daily Review, Inc., 383 F. Supp. 1346 (N.D. Cal. 1974), presents an example of the consequences of failing to recognize this problem. Only the fact of damage was before the court; plaintiffs relied on before-and-after comparisons to show that defendants' pricing policies had injured them. The court found, however, that:

Since plaintiffs' crucial profit and loss data, unlike that in Bigelow, was recorded and compiled well after the complaint was filed in the very litigation in which it was to be used to prove actual injury, its credibility is certainly suspect. Plaintiffs clearly had the opportunity to vary their gross incoine and expense figures during the "after" period in order to exaggerate the favorable impact that price increases might have on profitabiliity. Id. at 1382.

134. 500 F.2d 659 (5th Cir. 1974), cert. denied, 420 U.S. 929 (1975).

135. See 464 F.2d 26 (5th Cir.), cert. denied, 409 U.S. 1077 (1972).

136. 500 F.2d at 667-68. 
other stations. ${ }^{137}$ On the basis of these expense figures and the other data produced, lost profits were determined. Although Gulf objected to this method of proof on the grounds that the "yardstick stations" were not sufficiently similar to plaintiff's with respect to their expenses, the court found the argument unpersuasive. ${ }^{138}$

When a plaintiff alleges that a defendant's activities have caused him significant business mjury, the defendant's history since the inception of the alleged anticompetitive activity may also provide a meaningful yardstick. This was the case in Poster Exchange, Inc. v. National Screen Service Corp., ${ }^{139}$ in which a plaintiff's award of $\$ 150,000$ was affirmed. "[T] here is no doubt that there was ample basis for using [the Bigelow] formula here," the court held, ${ }^{140}$ explaining in a footnote that the plaintiff's established business had become less and less profitable while the defendant, "which started with nothing," simultaneously managed to capture most of the market through its predatory practices. ${ }^{141}$ The defendant's increase in profits was similarly used as a yardstick by which to ineasure the plaintiff's loss in C. Albert Sauter Co. v. Richard S. Sauter Co. ${ }^{142}$ In that case, mvolving the hiring of one firm's enployees by a competitor, the court noted that the plaintiff had lost sales of $\$ 400,000$ during the relevant period while the defendant had gained sales of $\$ 1.23$ million, ninety-four percent of which were to plaintiff's former chents. The court found this evidence properly submitted to the jury.

Problems in finding truly comparable firms make the yardstick test a difficult and rather easily disputed method of proof. ${ }^{143}$ As noted above, an attractive alternative may often be found in the more sophisticated modern projections of sales and profits developed on the basis of industry-wide data, opinion surveys, and the like. ${ }^{144}$ For example, in Terrell v. Household Goods Carriers' Bureau, ${ }^{145}$ the Fifth Circuit affirned a $\$ 900,000$ judgment based on a jury verdict which had been rendered after a presentation by a marketing and public opimion researcli expert. The expert had made a market study estimating the size

137. Id.

138. Id. at 669-70.

139. 431 F.2d 334 (5th Cir. 1970), cert. denied, 401 U.S. 912 (1971).

140. Id. at 340 .

141. Id. n.18. See also South-East Coal Co. v. Consolidated Coal Co., 434 F.2d 767 (6th Cir. 1970), cert. denied, 402 U.S. 983 (1971).

142. 368 F. Supp. 501, 508 (E.D. Pa. 1973). Other aspects of this case are discussed in the text accompanying notes 129-30 supra.

143. Cf. Morning Pioneer, Inc. v. Bismarck Tribune Co., 493 F.2d 383, 388 (8th

Cir.), cert. denied, 419 U.S. 836 (1974).

144. See notes 127-28 supra and accompanying text.

145. 494 F.2d 16 (5th Cir.), petition for cert. dismissed, 419 U.S. 987 (1974). 
of the relevant national market, relying in part on his own opinion studies. He also developed a "series of conclusions" which enabled hin to estimate the plaintiff's ability to penetrate the market, and then calculated the number of sales the plaintiff would have made in the national market had he stayed in business. ${ }^{140}$ Following this presentation, the plaintiff presented the testimony of a certified public accountant "who had prepared a net profit analysis based on actual known expense figures and the actual and projected sales figures adduced by the expert." 147 Other plaintiffs have succeeded by offering juries multiple profit projections based on a variety of assuinptions about sales, ${ }^{148}$ on profits and growth of the plaintiff before the alleged restraints of trade, ${ }^{149}$ and on posited potential penetration into markets from which the plaintiff had been excluded. ${ }^{150}$

The mere introduction of expert testimony will not guarantee recovery, of course; to be persuasive, the expert testimony must be developed from a factual basis on the record..$^{151}$ The court, it appears, must be convinced that the plaintiff is introducing the inost concrete evidence available to him, ${ }^{152}$ and that the proffered testimony has a reasonable relationship to the question at hand. Farmington Dowel Products Co. v. Forster Manufacturing Co. ${ }^{153}$ provides an example of the need for a reasonable basis in the record for such expert testimony. The First Circuit affirmed a trial court's exclusion of testimony which attempted to relate plaintiff's losses to the "average annual increase in the gross national product for the United States for the period 1951-1968" and to the "average annual imcrease in sales for all manufacturing companies for the same area and years."154 According to the court, the plaintiff had introduced no evidence which could support the attempted correlation between either of these measures and the projected volume of the company's business. ${ }^{155}$

146. Id. at 23.

147. Id.

148. Coleman Motor Co. v. Chrysler Corp., 376 F. Supp. 546 (W.D. Pa. 1974);

Power Replacement Corp. v. Air Preheater Co., 356 F. Supp. 872 (E.D. Pa. 1973).

149. Cook v. Ralston Purina Co., 366 F. Supp. 999 (M.D. Ga. 1973).

150. N.W. Controls, Inc. v. Outboard Marine Corp., 333 F. Supp. 493 (D. Del. 1971).

151. See, e.g., Lehrman v. Gulf Oil Corp., 500 F.2d 659, 668 (5th Cir. 1974), cert. denied, 420 U.S. 929 (1975).

152. See text following note 38 supra.

153. 421 F.2d 61 (1st Cir. 1969).

154. Id. at 82.

155. Id. 


\section{Good Will or Fair Market Value as Duplicative of Future Profits}

There has been substantial unanimity among the courts in recent years that a plaintiff who has been driven out of business by a defendant's anticompetitive practices cannot recover for both the profits he would have obtained in the future and the fair market value of his firm. A complete recent discussion of the issue occurred in Albrecht v. Herald $C o .{ }^{15 B}$ in which a contract newspaper carrier alleged that the paper's publisher had violated the Sherman Act by refusing to deal with the carrier, tluus forcing the carrier to sell his business at a loss. One question before the court of appeals was whether the plaintiff could properly recover both the fair market value of his business at the time of its sale, which tlie jury had set at $\$ 12,000$, and future profits lost as a result of the forced sale, which the jury had set at $\$ 57,000$. The trial court had reduced the latter award in response to a motion for judgment n.o.v., but otherwise allowed both awards to stand.

The Eighth Circuit found this improper, distinguishing a series of cases cited by the plaintiff as supporting sucli awards ${ }^{157}$ on the ground that "none of these cases allowed a plaintiff damaged by an antitrust violation to recover both the value of the business as a going concern at the time of the damage and future profits of that business after the time of the damage." 158 The future profit-earning potential of the plaintiff's business, the court held, is already taken into consideration in calculating the going-concern value of the firm. Thus, those cases wliich permitted recovery of going-concern value but not future profits were seen to provide the correct standard. ${ }^{159}$

156. 452 F.2d 124, 126-31 (8th Cir. 1971). The issue had been discussed a year earlier in Farmington Dowel Prod. Co. v. Forster Mfg. Co., 421 F.2d 61 (1st Cir. 1969) (as supplemented 1970).

A plaintiff can also recover lost future profits expected to be generated by a line of business into which it had not yet entered if there is shown to be an intention to enter the business and the preparedness to do so. See Woods Exploration \& Prod. Co. v. Aluminum Co. of America, 438 F.2d 1286, 1310 (5th Cir. 1971), cert. denied, 404 U.S. 1047 (1972), quoting Martin v. Phillips Petroleum Co., 365 F.2d 629 (5th Cir.), cert. denied, 385 U.S. 991 (1966); N.W. Controls, Inc. v. Outboard Marine Corp., 333 F. Supp. 493, 506-07 (D. Del. 1971).

157. The rejected precedents included Lessig v. Tidewater Oil Co., 327 F.2d 459 (9th Cir.), cert. denied, 377 U.S. 993 (1964); Osborn v. Sinclair Ref. Co., 324 F.2d 566 (4th Cir. 1963); Atlas Bidg. Prods. Co. v. Diamond Block \& Gravel Co., 269 F.2d 950 (10th Cir. 1959), cert. denied, 363 U.S. 843 (1960); and Twentieth Century-Fox Film Corp. v. Brookside Theatre Corp., 194 F.2d 846 (8th Cir.), cert. denied, 343 U.S. 942 (1952).

158. 452 F.2d at 129.

159. Id. at 129-30. 
The court also concluded that limiting the scope of the future profits award would not suffice to prevent duplication. "Capitalizing and discounting future profits is one method of figuring present value, but this does not mean that a person is entitled to present value plus future profits."100 A person "is not entitled to sell the route, receive full compensation therefor, and still receive the profits the route might have made over his reasonable work-life expectancy."161

In some situations, however, lost future profits provide an appropriate measure of damages. In Lehrman v. Gulf Oil Corp., ${ }^{162}$ for example, the defendants sought to limit the plaintiff, who liad gone out of business, to recovering the going-concern value of his service station at the time of its demise rather than lis potential future profits. The court of appeals twice rejected this argument. ${ }^{103}$

It seems clear that in some situations a plaintiff will be able to recover more if he establishes a loss of future profits than if he rests on proof of going-concern value. The possibility that different damage awards might result from the acceptance of alternative theories thus is a matter to which counsel should remam sensitive.

\section{Offsets and Mitigation}

It has long been held that a plaintiff who has enjoyed increased sales as a result of the very anticompetitive acts of which he complains cannot recover damages reflecting those increases. In Eastman Kodak ${ }^{104}$ for example, the Court approved a charge to the jury which instructed "that even if the plaintiff had not been a party to the monopoly, it could not recover damages on the basis of the profits which it had earned while a customer of the defendant to the extent that they had been mcreased by the monopoly and exceeded those in a normal business. . . ."165 Mitigation requirements reflect a similar primciple. For example, Hanover Shoe ${ }^{168}$ approved a deduction of an interest

160. Id. at 131.

161. Id. Since the Farmington Dowel and Albrecht cases, the Fifth and Sixth Circuits have adopted a similar stance. See Lehrman v. Gulf Oil Corp., 464 F.2d 26 (5th Cir.), cert. denied, 409 U.S. 1077 (1972), after remand, 500 F.2d 659 (5th Cir. 1974), cert. denied, 420 U.S. 929 (1975); Pollock \& Riley, Inc. v. Pearl Brewing Co., 498 F.2d 1240, $1244-45$ (5th Cir. 1974); Brewer v. Uniroyal, Inc., 498 F.2d 973 (6th Cir. 1974).

162. 464 F.2d 26 (5th Cir.), cert. denied, 409 U.S. 1077 (1972), after remand, 500 F.2d 659 (5th Cir. 1974), cert. denied, 420 U.S. 929 (1975).

163. 464 F.2d at $45 ; 500$ F.2d at 668 n.46.

164. 273 U.S. 359 (1927). See notes 13-16 supra and accompanying text.

165. Id. at 377 .

166. 392 U.S. 481 (1968). 
component from the plaintiff's profits to reflect the cost to the firm of funds borrowed to purchase the machines which it had been forced to lease. ${ }^{167}$

In inore recent years, these concerns have appeared in the context of potential reductions of the recoveries of plaintiffs forced out of business by anticompetitive actions by the amounts the plaintiffs have earned in new business activities. For example, in its first opinion in Lehrman v. Gulf Oil Corp., ${ }^{188}$ the Fifth Circuit remanded to the district court for redetermination of damages a Sherman Act case brought against Gulf by a service station operator. The appellate court specifically criticized the fact that "there was no allowance in the original jury verdict for mitigation of Lehrman's damages by the anount of his earnings in his current line of work." ${ }^{169}$ When Lehrman reached the court of appeals again two years later, ${ }^{170}$ the court re-emphasized that the only defect in the original district court charge had been the failure to instruct the jury "to allow for the mitigation of damages by the amount of Lehrman's earnings after he left the station."171

Mitigation of this sort is not automatic, however. For example, in Cook v. Ralston Purina Co. ${ }^{172}$ a partnership alleged anticompetitive practices on the part of a chicken feed distributor. These anticompetitive practices were shown to have resulted in a decline in the plaintiffs' feed warehousing business, which led the defendants to argue that plaintiffs had been freed to devote more time "to their general farming and associated operations"173 and that therefore the defendant was entitled to an offset for the value of these services to the plaintiffs. The court, sitting without a jury, rejected the claim. After considering the Lehrman precedent, the court distinguished the case before it. Its determination was clearly based on the degree of certainty of the evidence:

167. Id. at 502-04. It had been found that the defendant's refusal to sell constituted an illegal practice. See id. at 483-87.

168. 464 F.2d 26 (5th Cir.), cert. denied, 409 U.S. 1077 (1972), after remand, 500

F.2d 659 (5th Cir. 1974), cert. denied, 420 U.S. 929 (1975).

169. Id. at 46. The court continued:

[I]t appears that when Lehrman's gas business folded, he was freed for other paying forms of work, and that Lehrman could be damaged only by the excess of any lost future net profits over his actual earnings in alternative employment. Id. at $46-47$.

170. See Lehrman v. Gulf Oil Corp., 500 F.2d 659 (5th Cir. 1974), cert. denied, 420 U.S. 929 (1975).

171. 500 F.2d at 666 .

172. 366 F. Supp. 999 (M.D. Ga. 1973).

173. Id. at 1013 . 
In Lehrman the Plaintiff was put out of business by the Defendant's illegal acts and went to work elsewhere at a fixed salary, the amount of his actual earnings in his new occupation being shown by the evidence. In this case Harold Cook, who was chiefly responsible for the management of the warehouse operation, drew no salary from the warehouse operation. He and his brother were simply partners in the entire farm operation, part of which was the feed warehouse affected by the Defendant's restraint. He continued to spend part of his time in connection with the feed operation, but less time was required because of the reduced volume, and this meant that he doubtless spent more time (or could have spent more time) in assisting his brother in their other interests. But it is impossible to determine from the evidence whether this fact resulted in any improvement in the earnings from the other sources, and since the evidence does not show that Harold Cook had any earnings in alternative employment which were in any way attributable to any increased earning capacity on his part resulting from a slow-down in the feed business, the principle enunciated in Lehrman does not apply. ${ }^{174}$

Cook should be read by defense attorneys as encouraging discovery on the subject of a plaintiff's activities since the start of the alleged anticompetitive actions. It should also be noted that the eased burden of proof principles apphicable to the plaintiff's case, discussed above, ${ }^{175}$ are not here being applied with mutuality. However, this result is consistent with the purposes of the eased burden of proof - the recognition that a defendant should not be able to profit by his wrongdoing.

\section{E. Jury Knowledge of Trebling}

While rendering a verdict on damages is a role for the jury, it has long been established that entering a trebled judgment on that verdict is the court's responsibility. ${ }^{170}$ Whether the jury should be informed of this ultimate trebling has remained unsettled, however. Although there is older precedent to the contrary, ${ }^{177}$ most courts which have recently faced the issue have found it improper to inform the jury of the ultimate trebling of their award. ${ }^{178}$

174. Id.

175. See notes $12-85$ supra and accompanying text.

176. See, e.g., Eastman Kodak Co. v. Southern Photo Materials Co., 273 U.S. 359, 368 (1927).

177. See, e.g., Bordonaro Bros. Theatres v. Paramount Pictures, 203 F.2d 676, 679

(2d Cir. 1953); Cape Cod Food Prods. v. National Cranberry Ass'n, 119 F. Supp. 900

(D. Mass. 1954).

178. See Copper Liquor, Inc. v. Adolph Coors Co., 509 F.2d 758 (5th Cir. 1975); Lehrman v. Gulf Oil Corp., 500 F.2d 659, 667 (5th Cir. 1974), cert. denied, 420 U.S. 929 (1975); Pollock \& Riley, Inc. v. Pearl Brewing Co., 498 F.2d 1240, 1242 (5th Cir. 
The policy behind not informing the jury of trebling is the same as that which underpins the notion of treble damages itself. As Circuit Judge Tuttle wrote in Pollock \& Riley, Inc. v. Pearl Brewing Co., ${ }^{17 y}$ plaintiffs have a justifiable fear that juries would adjust damage awards downward or be inore reluctant to find liability in cases where treble damages threaten a "windfall" to the plaintiff. Such actions by juries would undercut the purposes of the treble damage action: deterrence of violations and encouragement of private enforcement of the antitrust laws. ${ }^{180}$ In addition, the role of the jury is to determine the amount of damage to the plaintiff, not the amount of judgment. ${ }^{181}$

One can expect defense attorneys to continue to raise this issue, for precisely the reasons stated by Judge Tuttle, until the Supreme Court has spoken. But the policy stated in Pollock \& Riley and other cases ${ }^{182}$ would appear to be sound and in keeping with the Supreme Court's repeated sympathy for the civil treble damages action.

\section{Other Damages Issues}

\section{A. The Fruits of Anticompetitive Actions}

Perhaps no award evidences the punitive purposes of the treble damages provision as starkly as a verdict against one conspirator supported by evidence of the injury suffered by a plaintiff at the liands of his co-conspirators. The appropriateness of such awards has been settled since at least the Story Parchment case, ${ }^{183}$ in which the Supreune Court affirmed a damage award against only one parchment manufacturer which reflected the damage caused to plaintiff by two companies' conspiratorial action. (The second firm was not made a defendant for lack of jurisdiction.) More recently, the Supreme Court affirmed a judgment against one participant in a patent pool whicl reflected the plaintiff's injury froin the anticompetitive actions of all meinbers of the pool. ${ }^{184}$

1974); Semke v. Enid Auto. Dealers Ass'n, 456 F.2d 1361, 1370 (10th Cir. 1972); C. Albert Sauter Co. v. Richard S. Sauter Co., 368 F. Supp. 501,517 (E.D. Pa. 1973). But see Standard Indus., Inc. v. Mobile Oil Corp., 475 F.2d 220 (10th Cir.), cert. denied, 414 U.S. 829 (1973).

179. 498 F.2d 1240 (5th Cir. 1974).

180. Id. at $1242-43$.

181. Id. at 1243.

182. See cases cited in note 178 supra.

183. 282 U.S. 555 (1931).

184. Zenith Radio Corp. v. Hazeltine Research, Inc., 395 U.S. 100. (1969). 
The appropriateness of these awards was re-emphasized in Wall Products Co. v. National Gypsum Co. ${ }^{185}$ The case arose from alleged anticompetitive practices in the gypsum board industry. In the hability phase of the case, the court had found a conspiracy among major gypsum board manufacturers to keep prices at an unjustifiable level. ${ }^{180}$ While some small manufacturers were willing to make the product available at lower prices, the court found that the major manufacturers had conspired to avoid lowering their prices to meet this competition. ${ }^{187}$ The suit had been brought against only four of the seven major gypsum board suppliers, however, and by the time the court reached its damages decision only two remained defendants. ${ }^{188}$ Nevertheless, the court held these defendants liable for the total damages suffered by the plaintiffs in purchases of gypsum board from all manufacturers, ${ }^{189}$ noting that " $[t]$ he law is . . . clear that . . . joint tortfeasors . . . are jointly and severally liable for any and all damages." 190

It is important to recognize that in these cases the plaintiffs were still recovering only for the damages they had suffered, not for the damages suffered by other potential plaintiffs. While a plaintiff may recover from one defendant for injuries it incurred through over-payments to other potential defendants, that plaintiff cannot recover damages suffered by other potential plaintiffs at the hands of that (or those) defendant(s). ${ }^{191}$

185. 357 F. Supp. 832 (N.D. Cal. 1973).

186. Wall Prod. Co. v. National Gypsum Co., 326 F. Supp. 295 (N.D. Cal. 1971).

187. This position of tolerance toward the single plant producer could only work if all major producers had a similar policy. It was clear that the moment one major producer started to meet the competition of a single plant producer the entire price structure would come tumbling down .... While the defendants could not get the single plant producers to agree to stop offering discounts and similar special deals, they could do the next best thing by keeping their own prices high. Id. at 320 .

188. A motion to dismiss was granted on behalf of one original defendant, Fibreboard Company, id. at 299. The fourth original defendant, Kaiser Gypsum Company, agreed to a settlement. $357 \mathrm{~F}$. Supp. at 834.

189. The court found the critical facts to be as follows:

[The conspiracy caused all major manufacturers to withdraw price deviations at the same time, December $15,1965 \ldots$ This termination of price competition by the major manufacturers naturally resulted in a higher price level for American, Republic, Big Horn and other single plant manufacturers. As a consequence, none of the plaintiffs, after Dec. 15,1965 , were able to receive any price lower than the prices charged by the conspirators USG, National and Kaiser. 357 F. Supp. at 840.

190. Id.

191. This point was emphatically made in GAF Corp. v. Circle Floor Co., 463 F.2d 752 (2d Cir. 1972), petition for cert. dismissed, 413 U.S. 901 (1973), in which a floor tile manufacturer accused four individuals and the named defendant of attempting to monopolize the New York metropolitan area floor tile market by gaining control of the plaintiff firm. The Second Circuit affirmed dismissal of the complaint, noting that

[t]he anti-competitive effect of the [defendants'] "conspiracy" or "attempt" 


\section{B. Attorneys' Fees}

It has been established for some time that attorneys' fees incurred in defending a patent infringement suit may be awarded as damages and may therefore be trebled if that suit is found to have constituted part of a course of conduct which violated the antitrust laws. ${ }^{192}$ Indeed, in the court of appeals decision in Hazeltine Research, Inc. v. Zenith Radio Corp ${ }^{193}$ the court held that "Zenith's expenses in defending the infringement suit brought pursuant to HRI's antitrust violations are a proper subject of threefold recovery," 194 and this point was undisturbed by the Supreme Court. ${ }^{195}$ More recently, the Eighth Circuit seems to have implicitly recognized such awards. ${ }^{196}$

These cases provide the basis for speculation about other cases in which litigation costs might be recoverable as damages. ${ }^{107}$ While most courts remain extremely cautious in awarding attorneys' fees as daunages, ${ }^{198}$ the rules stated would nonetheless allow awards in some situations. In Bendix Corp. v. Balax, Inc., ${ }^{199}$ for example, the Seventh Circuit denied damages for attorneys' fees generated in the defense of a

would be, the complaint alleges, a lessening of competition in the floor tile installation market, in that the "major [floor tile] contractors other than Circle Floor" would not have GAF as a source of supply, thus giving Circle Floor "decisive competitive advantages over other major contractors." In addition, the complaint alleges that . . potential competitors of GAF and Circle Floor, "may be discouraged or prevented from entering the . . f floor tile market." ... Thus the anti-competitive effects of the antitrust violations alleged by GAF would not be felt by GAF but by competitors of GAF and Circle Floor . . . . Id. at 757.

192. See, e.g., Dairy Foods Inc. v. Dairy Maid Prod. Cooperative, 297 F.2d 805 (7th Cir. 1961); Clapper v. Original Tractor Cab Co., 270 F.2d 616 (7th Cir. 1959), cert. denied, 361 U.S. 967 (1960); Malta Mfg. Co. v. Osteu, 215 F. Supp. 114, 123 (E.D. Mich. 1963), modified, 233 F. Supp. 462 (E.D. Mich. 1964).

193. 388 F.2d 25 (7th Cir. 1967), modified, 395 U.S. 100 (1969). See notes 35-38 supra and accompanying text.

194. $388 \mathrm{~F} .2 \mathrm{~d}$ at 35.

195. Zenith Radio Corp. v. Hazeltine Research, Inc., 395 U.S. 100 (1969).

196. See Acme Precision Prods., Inc. v. American Alloys Corp., 484 F.2d 1237, 1244 (8th Cir. 1973).

197. Language in a recent district court case would support an argument for fees outside of the patent-antitrust setting:

[T]here can be no doubt that up to the point that the reissue claims were dropped from this lawsuit after discovery that Mr. Beall was employed in prosecuting the reissue application, defeudants had to expend costs and attorneys' fees to defend themselves against plaintiff's monopolistic scheme and to this extent was injured in its business or property. Kearney \& Trecker Corp. v. Cincinnati Milacron, Inc., 1974-2 Trade Cas. If 75,438 at 98,483 (S.D. Ohio 1974).

198. See, e.g., Bendix Corp. v. Balax, Inc., 471 F.2d 149, 159 (7th Cir. 1972), cert. denied, 414 U.S. 819 (1973); Ansul Co. v. Uniroyal, Inc., 448 F.2d 872, 882-83 (2d Cir. 1971), cert. denied, 404 U.S. 1018 (1972).

199. 471 F.2d 149 (7th Cir. 1972), cert. denied, 414 U.S. 819 (1973). 
patent infringement suit, but plainly indicated that such an award would be appropriate where the patent suit was part of a conspiracy to restrain trade or to create a monopoly and was beyond the protection afforded by the patent rights. ${ }^{200}$ Thus, counsel should continue to be sensitive to the possibility of litigation costs being held to be recoverable damages when evaluating cases and advising clients.

\section{Conclusion}

The Supreme Court's consistent emphasis on the importance of antitrust policy to our economic system, and concurrently on the crucial role of private civil actions in furthering that policy, has led the Court to give every reasonable advantage to plaintiffs in private suits. This stance lias been evidenced in decisions reviewing antitrust civil action damage determinations, where the Court has significantly de-emphasized distmctions in the burdens to be met by the plaintiff in proving the "fact of injury" and the "amount of damage." Plaintiffs may now generally preserve, until the trial itself, proof of all issues relating to the damages. Lower courts liave been slow to follow the Court's lead; thus, there still remains considerable confusion in the danages areaconfusion which may disappear when the lower courts' decisions inore accurately reflect the overarching policy considerations which underlie the Supreme Court pronouncements.

200. Id. at 159. 